\title{
Correction to: The challenge of monoculturalism: what books are educators sharing with children and what messages do they send?
}

\author{
Helen Adam ${ }^{1}$ (D) . Caroline Barratt-Pugh ${ }^{2}$
}

Published online: 2 April 2020

(c) The Author(s) 2020

\section{Correction to: The Australian Educational Researcher https://doi.org/10.1007/s13384-019-00375-7}

The article "The challenge of monoculturalism: what books are educators sharing with children and what messages do they send?", written by Helen Adam and Caroline Barratt-Pugh, was originally published electronically on the publisher's internet portal on 05 February 2020 without open access. With the author(s)' decision to opt for Open Choice the copyright of the article changed on 02 April 2020 to (C) The Author(s) 2020 and the article is forthwith distributed under a Creative Commons Attribution 4.0 International License (https://creativecommons.org/licenses/by/4.0/), which permits use, sharing, adaptation, distribution and reproduction in any medium or format, as long as you give appropriate credit to the original author(s) and the source, provide a link to the Creative Commons licence, and indicate if changes were made.

The original article has been corrected.

Open Access This article is distributed under the terms of the Creative Commons Attribution 4.0 International License (http://creativecommons.org/licenses/by/4.0/), which permits use, duplication, adaptation, distribution and reproduction in any medium or format, as long as you give appropriate credit to the original author(s)

The original article can be found online at https://doi.org/10.1007/s13384-019-00375-7.

Helen Adam

h.adam@ecu.edu.au

Caroline Barratt-Pugh

c.barratt-pugh@ecu.edu.au

1 Edith Cowan University, 2 Bradford Street, Mount Lawley, WA 6050, Australia

2 School of Education, Edith Cowan University, 2 Bradford Street, Mount Lawley, WA 6050, Australia 
and the source, provide a link to the Creative Commons license and indicate if changes were made.

Publisher's Note Springer Nature remains neutral with regard to jurisdictional claims in published maps and institutional affiliations. 